\title{
Prostate carcinoma skeletal metastases: Cross-talk between tumor and bone
}

\author{
Evan T. Keller ${ }^{1}$, Jian Zhang ${ }^{1}$, Carlton R. Cooper ${ }^{2}$, Peter C. Smith ${ }^{1}$, Laurie K. McCauley ${ }^{3}$, \\ Kenneth J. Pienta ${ }^{2}$ and Russell S. Taichman ${ }^{3}$ \\ ${ }^{1}$ Unit for Laboratory Animal Medicine, ${ }^{2}$ Department of Surgery, ${ }^{3}$ Department of \\ Periodontics/Prevention/Geriatrics, University of Michigan, Ann Arbor, MI, USA
}

Key words: prostatic neoplasms, skeletal metastases, bone morphogenetic protein, parathyroid hormone-related protein, stromal-derived factor, matrix metalloproteinase

\begin{abstract}
The majority of men with progressive prostate cancer develop metastases with the skeleton being the most prevalent metastatic site. Unlike many other tumors that metastasize to bone and form osteolytic lesions, prostate carcinomas form osteoblastic lesions. However, histological evaluation of these lesions reveals the presence of underlying osteoclastic activity. These lesions are painful, resulting in diminished quality of life of the patient. There is emerging evidence that prostate carcinomas establish and thrive in the skeleton due to cross-talk between the bone microenvironment and tumor cells. Bone provides chemotactic factors, adhesion factors, and growth factors that allow the prostate carcinoma cells to target and proliferate in the skeleton. The prostate carcinoma cells reciprocate through production of osteoblastic and osteolytic factors that modulate bone remodeling. The prostate carcinoma-induced osteolysis promotes release of the many growth factors within the bone extracellular matrix thus further enhancing the progression of the metastases. This review focuses on the interaction between the bone and the prostate carcinoma cells that allow for development and progression of prostate carcinoma skeletal metastases.
\end{abstract}

\section{Introduction}

Prostate carcinoma is the most frequently diagnosed cancer in men and the second leading cause of cancer death among men in the United States [1]. The most common site of prostate carcinoma metastasis is the bone with skeletal metastases identified at autopsy in up to $90 \%$ of patients dying from prostate carcinoma [2-4]. Skeletal metastasis results in significant complications that diminish the quality of life in affected patients. These complications include bone pain, impaired mobility, pathological fracture, spinal cord compression and symptomatic hypercalcemia [5-7]. Despite advances in the diagnosis and management of prostate carcinoma, advanced disease with skeletal metastasis remains incurable. Current therapeutic modalities are mostly palliative, and include hormonal therapy, pharmacological management of bone pain, radiotherapy for pain and spinal cord compression [8], various chemotherapy regimens, and the use of bisphosphonates to inhibit osteoclast activity [9]. In spite of the severe complications of prostate carcinoma skeletal metastasis, there have not been many advances in the therapeutic arena to prevent or diminish these lesions. It is critical that a solid understanding of the pathophysiology of prostate carcinoma skeletal metastatic process is developed to provide the basis for creating strategies to prevent or diminish their occurrence and associated complications. A preponderance of evidence suggests that establishment and progression of prostate carcinoma bone metastases is dependent on interaction between the bone microenvironment and the prostate carcinoma cell through both soluble and cell-membrane bound bioactive factors. In this review, we will summarize some of the cross-talk mechanisms between bone and prostate carcinoma.

\section{The effects of bone on prostate carcinoma metastasis}

In agreement with the 'seed and soil' theory of metastases espoused by Paget [10], the predilection of prostate carcinoma to establish metastases in bone as 
opposed to other organs suggests that the bone microenvironment offers a fertile soil for prostate carcinoma growth. Prior to interacting on the bone cells and bone matrix, the prostate carcinoma cells must enter the bone compartment. This is accomplished by several general mechanisms that include chemotaxis from the circulation, attachment to bone endothelium, extravasation, and invasion. The bone microenvironment is a complicated mixture of mineralized and non-mineralized bone matrix and endothelial, hematopoietic, immune, and bone marrow stromal cells. Each of these components of the bone microenvironment may contribute to the establishment of prostate carcinoma metastases through provision of chemotactic, angiogenic, adhesion and growth factors.

\subsection{Chemotaxis}

When prostate carcinoma cells are injected adjacent to adult human bone implanted in SCID mice, the prostate carcinoma cells to migrate to adult human bone [11] This observation provides evidence that bone provides chemotactic factors for prostate carcinoma cells. This is further supported by the observation that bone undergoing active resorption facilitated adhesion [12] and chemotaxis $[13,14]$ of tumor cells to bone compared to non-resorbing bone. Collagen products appear to be one component of bone that induces tumor chemotaxis [15]. The factors through which bone induces chemotaxis are not clear. However, low glycosylated osteonectin was found to be an active chemotaxic factor in crude bone extracts that promoted chemotaxis of human prostate epithelial cells and increased the invasive ability of human prostate carcinoma cells [16]. In contrast with this observation, purified fibronectin, but not crude bone extracts induced migration of the prostate carcinoma DU-145 cell line [17]. Cell line specificity may account for these differences. Epidermal growth factor induced migration of the TSU-pr1 prostate carcinoma cell line [18]. Since EGF is present in medullary bone, this observation suggests that it may act as a chemotactic factor for bone metastases. Finally, the Rho-kinase inhibitor, Y-27632, inhibited in vitro chemotactic migration to bone marrow fibroblast conditioned media and metastatic growth in immune-compromised mice of highly invasive human prostatic cancer (PC3) cells [19]. This observation suggests that modulation of kinase activity may prove fruitful in inhibition of skeletal metastasis.

In addition to the above substances, which typically are not considered chemotactic factors, prostate carcinoma cells may commandeer the normal leukocyte bone marrow homing mechanism using the chemokine pathway [20]. Chemokines are classified based upon the relative position of cysteine residues near the NH2-terminus into four major families: $\mathrm{CC}, \mathrm{CXC}, \mathrm{C}, \mathrm{CX}_{3} \mathrm{C}$ (as reviewed in [21]). Chemokines activate receptors that are members of the large family of seven-transmembrane $G$ protein-coupled proteins. In addition to the role that chemokines have in cell migration, they play significant roles in normal development, inflammation, atherosclerosis and angiogenesis. The rapidly increasing knowledge of chemokines has begun to impact many aspects of tumor biology including modulation of proliferation, angiogenesis and immune response to tumor (as reviewed in [22]).

An important role for chemokines may be to regulate metastatic behavior. Localization in tissues and migration to target organs are essential steps in the pathobiology of metastasis which strongly support the analogy to hematopoietic cell homing. In this context, the CXC chemokine stromal-derived factor (SDF-1; CXCL12) and its receptor, CXCR4 appear to be critical molecular determinants for these events $[23,24]$. This has been substantiated in gene knockout investigations $[25,26]$ and by the demonstration that level of CXCR4 expression correlates with the ability of human hematopoietic progenitors to engraft into nude mice [26]. In the bone marrow, SDF-1 is constitutively produced by osteoblasts, fibroblasts and endothelial cells [27]. However, not all vascular endothelial cells express SDF-1, suggesting that organ-specific expression SDF-1 may account for the selectivity of metastases to target certain organs [28].

Several lines of evidence suggest that SDF-1 contributes to the pathogenesis of prostate carcinoma metastases. Inhibition of chemokines diminished in vitro proliferation of PC-3 cells [29] and antiCXCR2 antibody inhibited IL-8-stimulated migration of PC-3 cells in vitro [30]. These studies suggest that chemokines contribute to prostate metastatic pathophysiology. This possibility is reinforced by the observation that CXCR4 is expressed in normal prostate tissues, albeit at low levels [31], as well as several neoplasms that invade the marrow (e.g., breast cancers, Burkitt's lymphoma, leukemias) [31-33]. Furthermore, several prostate carcinoma cell lines express CXCR4 mRNA, and SDF-1 increased migration of these cells in vitro [34]. It was recently demonstrated that normal breast tissues express little CXCR4, whereas breast neoplasms express high levels of CXCR4 [35,36], and antibody to CXCR4 blocked the 
metastatic spread of the tumors to the bone in an experimental metastasis model [35]. Taken together, these data suggest that SDF-1 and CXCR4 are likely critical regulators of prostate carcinoma metastasis to bone.

\subsection{Attachment to endothelium}

Cell adhesion plays a vital role in cancer metastasis. In fact, the ability of cancer cells to adhere to organ-specific cells and components may be a critical regulator of their metastatic pattern. A cancer cell in the circulation initially interacts with the organ's microvascular endothelium and subsequently the organ's extracellular matrix (ECM) components [37,38]. Cell adhesion molecules (CAMs) expressed on both the cancer and endothelial cells mediate these interactions. CAMs expressed on the endothelial cells are regulated by an organ's microenvironment, which results in CAM expression specific to each organ [39]. The organ-specific composition of ECM proteins such as laminin, fibronectin, and vitronectin that are recognized by CAMs expressed on cancer cells contribute significantly to organ-specific metastasis $[40,41]$.

It has been proposed that prostate carcinoma metastasis to bone is mediated, in part, by preferential adhesion to bone marrow endothelium as opposed to endothelium from other sites $[42,43]$. Two studies demonstrated that prostate carcinoma cells adhered preferentially to immortalized human bone marrow endothelial (HBME) cells as compared to human umbilical vein endothelial cells (HUVEC), immortalized human aortic endothelial cells (HAEC-I), and immortalized human dermal microvascular endothelial cells (HDMVEC) [42,44]. This observation was confirmed in another study that demonstrated preferential adhesion of PC-3 cells to HBME cells as compared to HUVECs and lung endothelial cells, Hs888Lu [45]. Interestingly, this adhesion was enhanced when HBME cells were grown on bone ECM components [44]. The PC-3 cell line was used as a model for prostate carcinoma in these studies because it was derived from a bone metastasis. To determine the CAMs involved in prostate carcinoma (PC)-HBME interaction, galactose-rich-modified citrus pectin (MCP) and several antibodies to known CAMs expressed on HBME cell monolayers, were used in adhesion assays. MCP was used because it was reported to interfere with interactions mediated by carbohydratebinding proteins such as galectins [46]. The data demonstrated that MCP and antibodies to galectin3 , vascular cell adhesion molecule (VCAM), CD11a
(alpha-L), CD18 (beta-2), and leukocyte functional antigen-1 (LFA-1) pectin, reduced PC-3 cell adhesion to HBME cell monolayers [42]. This observation suggests that carbohydrate-binding proteins, VCAM, alpha-L, beta-2, and LFA-1 may be partially involved in prostate carcinoma cell adhesion to HBME cells. Beta-1 integrins expressed on HUVEC were demonstrated to mediate PC-3 cell adhesion to this endothelial cell line [47]. Surprisingly, the beta-1 integrins expressed on HBME cells were not involved in PC-3 cell adhesion to HBME cell monolayers [48]; however, beta- 1 integrins, expressed on PC-3 cells, did mediate its interaction with HBME cell monolayers [45]. Hyaluronan and galactosyl receptor, a cell surface C-type lectin expressed on PC-3 cells, were also shown to mediate PC-HBME interaction $[49,50]$.

The ability of metastatic prostate cells to adhere to the bone matrix may also contribute to prostate carcinoma frequent metastasis to bone matrix [51,52]. Kostenuik demonstrated that PC-3 cells adhered to the collagen type $\mathrm{I}$ in the bone matrix. This adhesion was mediated by $\alpha 2 \beta 1$ expressed on PC-3 cells and was upregulated by transforming growth factor- $\beta$ (TGF- $\beta$ ), a major bone-derived cytokine [53]. Festuccia and colleagues [52] showed that osteoblast-conditioned media containing TGF- $\beta$, modulated the PC-3 interaction with ECM proteins, including collagen type I. These results provide evidence that TGF- $\beta$, present in the bone marrow, can influence prostate carcinoma cell adhesion to the bone matrix by modulating surface expression of selected integrins.

\subsection{Growth factors}

The calcified bone matrix is replete with putative prostate carcinoma growth factors including insulinlike growth factors (IGF), bone morphogenetic proteins (BMP), fibroblast growth factors (FGF) and transforming growth factor (TGF)-beta, which are released upon resorption of bone [54,55]. Furthermore, experimental evidence that resorption of calcified bone matrix promotes tumor growth was suggested by the observation that conditioned media for bone cultures undergoing resorption stimulated cancer cell growth of a variety of tumor cell lines [56]. Taken together, these data suggest that inhibiting bone resorption will diminish cancer growth by decreasing growth factors availability in the bone microenvironment.

Several purified factors from bone matrix have been demonstrated to stimulate prostate carcinoma cell growth in vitro [57-59]. For example, IGF-I 
and IGF-II are important mediators of prostate carcinoma growth (as reviewed in $[60,61]$ ). Prostate carcinoma cells have IGF receptors [62] and proliferate in response to IGF [57]. Transfection of LNCaP cells with FGF-8 expression vector induced an increased growth rate, higher soft agar clonogenic efficiency, enhanced in vitro invasion, and increased in vivo tumorigenesis [58]. The source of these growth factors is diverse. For example, osteoblast-derived factors influence prostate carcinoma growth, adhesion, and motility $[16,17,63]$. Additionally, bone marrow stromal cells, as opposed to non-skeletal fibroblasts, induced prostate carcinoma cell growth in vitro and in vivo [64-66]. As research continues on the extracellular matrix of bone, it is very likely that additional prostate carcinoma growth factors will be discovered.

\section{The effect of prostate carcinoma on the bone: Osteoblastic}

\subsection{Prostate skeletal metastases are mixed osteoblastic and osteolytic lesions}

Once in the bone, prostate carcinoma tumors have pathobiology that appears to be somewhat unique to cancer skeletal metastases. Specifically, prostate carcinoma skeletal metastases are most often characterized as osteoblastic (i.e., increased mineral density at the site of the lesion) as opposed to osteolytic. Other tumors, such as breast cancer, can form osteoblastic lesions; however, these occur less frequently $[67,68]$. In spite of the radiographic osteoblastic appearance it is clear from histological evidence that prostate carcinoma metastases form a heterogeneous mixture of osteolytic and osteoblastic lesions although osteoblastic lesions predominate [69-72]. Sites of prostate carcinoma bone metastases are often demonstrated to have increases in osteoid surface, osteoid volume, mineralization rates [73,74]. Recent evidence shows that osteoblastic metastases form on trabecular bone at sites of previous osteoclastic resorption, and that such resorption may be required for subsequent osteoblastic bone formation [75,76]. Clinical evidence demonstrates increased systemic markers of both bone production and bone resorption in prostate carcinoma patients $[77,78]$ in addition to bone histomorphometric findings of increased indices of bone resorption [71]. These findings suggest that prostate carcinoma induces bone production through an overall increase in bone remodeling, which in the non-pathologic state is a balance between osteoclastic resorption of bone and osteoblast-mediated replacement of resorbed bone (as reviewed in [79-81]). In the case of prostate carcinoma, it appears the induction of osteoblast-mediated mineralization outweighs the increase in osteoclast resorption resulting in overall formation of osteoblastic lesions. The osteoblastic lesions result in overall weakening of the bone for the following reasons; mature, healthy bone is formed of lamellar bone, which allows for tight packing of collagen bundles and optimum bone strength. In contrast, prostate carcinoma induces production of woven bone, which is composed of loosely packed, randomly oriented collagen bundles that produce bone with suboptimal strength $[82,83]$. Thus, the combination of underlying osteolysis and production of weak bone leads to a predisposition to fracture. The mechanisms through which prostate carcinoma cells promote bone mineralization remain poorly understood.

\subsection{A variety of factors may contribute to prostate carcinoma-mediated bone mineralization}

Prostate carcinoma produces osteoblastic factors that mediate their effect through activation of the osteoblast transcription factor $\mathrm{Cbfa} 1$ in the osteoblast precursor [84]. This suggests that induction of osteosclerosis occurs through normal osteoblast differentiation pathways. In addition to this observation, the prostate carcinoma cell itself demonstrates increased expression of Cbfa1 an the ability to mineralize in vitro, suggesting that it directly contributes to osteosclerosis [85]. Many factors that have direct or indirect osteogenic properties have been implicated in prostate carcinoma's osteogenic activity (Table 1) (as reviewed in [86, 87-89]). Although, initially identified as a nondefined osteoblastic activity from prostate carcinoma cells in vitro [90], many specific factors have been

Table 1. Osteogenic factors produced by cancer cells

\begin{tabular}{ll}
\hline Factor & Reference \\
\hline Bone morphogenetic proteins (BMP) & {$[93,169]$} \\
Endothelin-1 (ET-1) & {$[94,136]$} \\
Insulin-like growth factors (IGF) & {$[231,232]$.} \\
Interleukin-1 and -6 & {$[233,234]$} \\
Osteoprotegerin (OPG) & {$[100,101]$} \\
Parathyroid hormone-related peptide (PTHrP) & {$[96,97]$} \\
Transforming growth factor- $\beta$ (TFG- $\beta$ ) & {$[99]$} \\
Urinary plasminogen activator (urokinase) & {$[235]$} \\
\hline
\end{tabular}


identified that may promote osteoblastic lesions. Some of these factors, such as bone morphogenetic proteins (BMP) [91-93] and enodothlin-1 (ET-1) [94] may directly stimulate differentiation of osteoblast precursors to mature mineral-producing osteoblasts [95] or induce osteoblast protein production [93]. Other factors such as parathyroid hormone-related protein (PTHrP) may work through inhibition of osteoblast apoptosis $[96,97]$. Additionally, there are proteins that may work indirectly to enhance bone production, such as the serine proteases, prostate specific antigen (PSA) and urinary plasminogen activator (uPA), which can activate latent forms of osteogenic proteins, such as transforming growth factor- $\beta$ (TFG- $\beta$ [98,99]. Finally, some molecules, such as osteoprotegerin (OPG) [100-102] and ET-1 (in a dual role with its osteoblast-stimulating activity) [103] can enhance osteosclerosis through inhibiting osteoclastogenesis. Other tumor types, such as osteosarcoma, are also known to produce a variety of osteoblastic factors [104-106]. With such a large number of factors, it is difficult to determine which the key factor is, and most likely several of these osteogenic factors work in concert to produce maximal bone production.

\subsubsection{Parathyroid hormone related protein $(\mathrm{PTHrP})$} PTHrP was originally identified as a tumor-derived factor responsible for humoral hypercalcemia of malignancy (HHM). It has limited homology with the endocrine hormone, parathyroid hormone, sharing 7 of the first $13 \mathrm{~N}$-terminal amino acids, but otherwise is dissimilar and immunologically distinct [107]. PTH AND PTHrP bind to the same receptor (the PTH-1 receptor) and evoke the same biological activity due to similarities in their steric configurations at the region of 25-34 amino acids. Patients with solid tumors and hypercalcemia have increased serum PTHrP in $80 \%$ of the cases, emphasizing the impact of this peptide to increase bone resorption and renal tubular resorption of calcium [107]. Subsequent to its characterization in HHM, PTHrP was found to be produced by many normal tissues including, epithelium, lactating mammary gland, and cartilage where it has an autocrine, paracrine, or intracrine role [107]. PTHrP plays a critical role in the development of the skeleton as evidenced by its lethality upon gene ablation and the severe skeletal chondrodysplasia found in these animals [108]. These studies have led to the conclusion that PTHrP in cartilage functions to accelerate the growth of cartilage cells and to oppose their progression to a terminally differentiated cell [109].
Many features of PTHrP make it an attractive candidate for influencing prostate carcinoma growth. PTHrP is produced by normal prostate epithelial cells, from which prostate carcinoma arises, and PTHrP is found in the seminal fluid [87,110]. PTHrP has been immunohistochemically identified in prostate carcinoma tissue in patients with clinically localized disease [111], is found in higher levels in prostate intraepithelial neoplasia than in normal prostate epithelium, is found in higher levels in prostate carcinoma than in benign prostatic hyperplasia [112,113], and is found in human metastatic lesions in bone [114]. There is also evidence that PTHrP can regulate malignant tumor growth in an autocrine manner in human renal cell carcinoma [115], enhance breast cancer metastasis to bone [116,117], and act as an autocrine growth factor for prostate carcinoma cells in vitro [118]. Recent evidence indicates that expression of nuclear-targeted PTHrP can protect prostate and other cells from apoptosis [114,119], bind RNA [120], and act as a mitogen [121,122]. PTHrP production by primary prostatic tumors is associated with increased tumor size and rate of growth in an animal model [114] suggesting that PTHrP acts in autocrine or intracrine mechanisms to promote tumor growth. In contrast, in this same model and in an intracardiac injection model of prostate carcinoma, PTHrP was not associated with an increase in metastatic potential [83,114]. This suggests that PTHrP is not important in the process of metastasis to bone but once in the bone microenvironment where target cells with receptors are present (osteoblasts); it may play a critical role in the bone response to prostate carcinoma. Of particular interest to prostate carcinoma, PSA has been shown to cleave PTHrP leading to an inactivation of the PTHrP-stimulation of cAMP which is a key pathway for the actions of PTHrP in bone [123]. More recent studies indicate that in colon cancer cells, PTHrP enhances adhesion of cells to type I collagen but not fibronectin or laminin [124]. All these data suggest that PTHrP has a critical role in the local bone microenvironment of metastatic prostate carcinoma; but what this precise role is has yet to be determined.

\subsubsection{Endothelin-1}

ET-1 is a member of the ET family which is composed of ET-1, -2 , and -3 . The ET family members are synthesized as a 203 amino acid precursor peptide that is cleaved to a 21 amino acid peptide with the same two characteristic disulfide bridges [125]. Initially 
identified as a potent vasoconstrictor, ET-1 interacts with cell surface $\mathrm{ET}_{\mathrm{A}}$ and $\mathrm{ET}_{\mathrm{B}}$ receptors to induce a variety of responses including modulation of cell growth and fetal development (as reviewed in [125]). ETs are found in a variety of tissues including vascular endothelium, parathyroid gland, mammary tissue, and macrophages [125].

The role of ET-1 in bone remodeling is controversial. For example, in the murine osteoblast precursor cell, MC3T3-E1, E1 inhibits differentiation, reduces both alkaline phosphatase activity and osteocalcin expression and diminishes in vitro mineralization suggesting that ET-1 will diminish bone production [126,127]. In contrast, ET-1 has been shown to inhibit bone resorption [128], induce collagen synthesis [129] and osteopontin and alkaline phosphatase production [130,131] in a variety of osteoblastic cell lines. The conflicting results may be due to differences in cell lines, particularly with regards to ET receptor expression. Although these in vitro data are in apparent conflict, the in vivo data support that ET-1 promotes bone formation [132]. Specifically, administration of an $\mathrm{ET}_{\mathrm{A}}$ receptor antagonist in mice resulted in reduced bone mass [132].

ET-1 is secreted by normal prostate epithelial cells into the ejaculate [133-135] and is now considered a putative mediator of prostate carcinoma pathophysiology (as reviewed in [136]). The ectopic expression of ET- 1 in the bone metastatic site by prostate carcinoma cells may enable ET-1 to influence the bone remodeling process locally. This is supported by the report that para-tibial injection of an amniotic cell line overexpressing ET-1 induced new bone formation in the tibiae of mice, which was diminished by blockade of $\mathrm{ET}_{\mathrm{A}}$ receptor [137]. Additionally, administration of an ETA receptor antagonist diminished breast cancerinduced bone production in a murine model [138]. Furthermore, co-incubating the androgen-independent prostate carcinoma cell lines DU-145 and PC-3, but not the androgen-responsive cell line LNCaP, with bone slices induced ET-1 expression from the prostate carcinoma cells [103]. The DU-145 and PC-3 cell lines also induced osteoclastogenic activity that was blocked by anti-human ET-1 antibody. Taken together, these reports suggest that ET-1 may contribute to prostate carcinoma metastases-induced osteoblastic lesions. In apparent conflict with these models, is the observation that serum ET-1 levels are elevated in people with Paget's disease, which is characterized by low bone mineral density secondary to increased osteoclastic activity [139].

\subsubsection{Bone morphogenetic proteins}

BMPs are members of the transforming growth factor (TFG)- $\beta$ superfamily. More than 30 BMPs have been identified to date [140]. While originally discovered because of their ability to induce new bone formation, BMPs are now recognized to perform many functions, particularly in the role of development, such as apoptosis, differentiation, proliferation and morphogenesis (as reviewed in [141-143]). BMPs are synthesized as large precursor molecules that undergo proteolytic cleavage to release the mature protein, which form active hetero- or homodimers [144,145]. BMPs bind to receptors (BMPR-IA and -IB) and a BMP type II receptor (BMPR-II), which induces Smad phosphorylation [146] resulting in modulation of gene regulation. Target genes of BMPs include osteoblast proteins such as OPG [147] and the osteoblast-specific transcription factor Cbfa-1 [148,149]. Several proteins that antagonize BMP action have been identified. For example, noggin and gremlin inhibit BMP-2, -4 and -7 by binding to them [150-152]. Furthermore, the BMPs themselves regulate their own inhibitors in an apparent negative feedback mechanism [153,154].

Many in vitro studies have demonstrated that BMPs induce osteogenic differentiation including the ability of BMP-7 (also called osteogenic protein-1; OP-1) to induce osteogenic differentiation of newborn rat calvarial cells and rat osteosarcoma cells [155-157]. The BMPs' osteogenic properties appear to be specific to the differentiation stage of the target cells. Specifically, BMPs can induced uncommitted stem cells $[155,158,159]$ and myoblasts [160] to express osteoblast parameters such as alkaline phosphatase or osteocalcin expression [79,161]; whereas, BMPs do not stimulate mature osteoblasts or fibroblasts $[158,162-164]$ to increase expression of these proteins. Examination of genetically modified mice provides further evidence of the importance of BMP in bone development. The $b m p 7$ homozygous null condition in mice is a postnatal lethal mutation and is associated with, in addition to renal and ocular abnormalities, retarded skeletal ossification [165]. In contrast, bmp6 null mice are viable and fertile, and the skeletal elements of newborn and adult mutants are indistinguishable from wildtype [166]. However, careful examination of skeletogenesis in late gestation embryos reveals a consistent delay in ossification strictly confined to the developing sternum. Finally, mice with mutations of the bmp5 gene have skeletal abnormalities and inefficient fracture repair [167]. Taken together, these data provide 
evidence that BMPs are important regulators of the osteogenesis. Thus, dysregulation of their expression in the bone microenvironment would most likely impact bone remodeling.

A few studies have examined the expression of BMPs in normal and neoplastic prostate tissues. Using Northern analysis, Harris et al. [92] examined BMP-2, -3, -4 and -6 mRNA expression in human normal prostate and prostate carcinoma cell lines. They found that normal human prostate predominantly expressed BMP-4. The androgen-dependent non-metastatic LNCaP human prostate carcinoma cell line produced very low to undetectable levels of BMPs. Whereas, the aggressive androgen-independent PC-3 cell line expressed very high levels of BMP-3 and slightly lower levels of BMP-2, -4 and -6 compared to normal cells, but much higher than $\mathrm{LNCaP}$ cells. In support of these results, Weber et al. [168], using PCR analysis, identified $16(73 \%)$ of 22 prostate carcinoma samples that were positive for BMP-7 mRNA compared to eight $(57 \%)$ of 14 normal prostate tissue samples. In another PCR based analysis, Bentley et al. [169], found that several BMPs were expressed in both benign and malignant prostate tissue and in the PC3 and DU145 prostate carcinoma cell lines. BMP-6 expression was detected in the prostate tissue of over $50 \%$ of patients with clinically defined metastatic prostate adenocarcinoma, but was not detected in non-metastatic or benign prostate samples. In another study focused on BMP-6 mRNA and protein expression, Barnes et al. [170] observed that BMP-6 was produced by normal and neoplastic human prostate (radical prostatectomy specimens and human carcinoma cell lines DU145 and PC3). However, BMP-6 mRNA and protein expression was higher in prostate carcinoma as compared with adjacent normal prostate, with higher-grade tumors (Gleason score of 6 or more) having greater BMP-6 immunostaining than the lower-grade tumors (Gleason score of 4 or less). These results were consistent with a later study by Hamdy et al. [171], who reported that BMP-6 mRNA expression was detected exclusively in malignant epithelial cells in 20 of 21 patients $(95 \%)$ with metastases, in 2 of 11 patients (18\%) with localized cancer, and undetectable in 8 benign samples. In addition to BMP, there have been several reports that prostate carcinoma expresses BMP receptors. It appears that as prostate carcinoma progress, the cells down-regulate their own expression of BMP receptors $[172,173]$, which may be a protective mechanism as it has been demonstrated that BMP-2 can inhibit prostate carcinoma cell proliferation [174]. Taken together, these observations demonstrate that prostate carcinoma cells produce increasing levels of BMPs as they progress to a more aggressive phenotype and suggest that the up-regulation of BMP expression in prostate carcinoma cells localized in the bone is a critical component of the mechanism of development of osteoblastic lesions at prostate carcinoma metastatic sites.

\section{The effect of prostate carcinoma on the bone: Osteolytic}

Although the osteoblastic component of prostate carcinoma metastases has received attention, limited research has been performed on the osteoclastic aspect of prostate carcinoma. Similar to the reports for breast cancer bone metastases $[175,176]$, several lines of evidence suggest that resorption of bone is an important mediator of prostate carcinoma bone metastases. For example, administration of bisphosphonates, inhibitors of osteoclast activity, to patients with prostate carcinoma bone metastases relieves bone pain and lowers systemic indices of bone resorption [177-179]. Furthermore, administration of osteoclast inhibitors such as OPG or bisphosphonates prevents tumor establishment or diminished tumor burden in animal models [76,180-182]. It is not clear if bisphosphonates have a direct antitumor effect [183-185] or inhibit tumor growth through its ability to diminish osteoclast activity $[186,187]$. In some instances, it may be a combination of activities. As described above, in addition to serum levels of bone resorption markers being elevated in men with prostate carcinoma skeletal metastases, the lesions usually are demonstrated to have histological evidence of osteoclast activity. Thus, osteoclast activity may play an important role in development and progression of prostate carcinoma metastases. Prostate carcinoma cells secrete a variety of factors that may promote bone lysis, such as interleukin-6 (as reviewed in [188]) and PTHrP. However, it appears that these factors mediate their osteolytic effects through induction of a key pro-osteoclastogenic molecule, receptor activator of $\mathrm{NF} \kappa \mathrm{B}$ ligand (RANKL).

\subsection{Receptor activator of $N F k B$ ligand-OPG axis}

A member of the tumor necrosis factor family, RANKL is initially expressed as a membrane anchored molecule; however, a small fraction of RANKL is released 
through proteolytic cleavage from the cell surface as a soluble 245 amino acid homotrimeric molecule (sRANKL) [189]. Both soluble and membrane bound RANKL promote osteoclast formation and activation by binding to RANK on the osteoclast precursor membrane [189-193].

In addition to RANKL and RANK, another key modulator of osteoclastogenesis is osteoprotegerin (OPG)(also known as osteoclastogenesis inhibitory factor-OCIF) [102,194]. OPG serves as a decoy receptor that binds RANKL and thus blocks its ability to bind to RANK and induce osteoclastogenesis. In contrast to RANKL and RANK, whose expression is mainly restricted at low levels to the skeletal and immune systems, OPG is expressed in a variety of tissues, such as liver, lung, heart, kidney, stomach, intestines, skin and calvaria in mice and lung, heart, kidney and placenta in human [102,195-201]. In bone, OPG is mainly produced by osteoblastic lineage cells and its expression increases as the cells become more differentiated [199,202,203]. Administration of recombinant OPG to normal rodents resulted in increased bone mass [102,196] and completely prevented ovariectomy-induced bone loss without apparent adverse skeletal and extraskeletal side effects [102]. In fact, based on this activity, the balance ratio of RANKL to OPG appears to be very important in controlling the overall activity (i.e., lysis vs no lysis) that will be observed [204-206].

A number of reports have shown that osteoclastic bone resorptive lesions are important to the development of bone metastases in several cancer types including breast cancer, lung cancer and prostate carcinoma [207]. These cancers may induce osteoclast activity through secretion of IL- $1 \alpha$, PTHrP or PGE2 [208,209]. However, tumor-mediated osteolysis occurs indirectly through expression of molecules, such as PTHrP, that induce RANKL in osteoblasts [210,211]. This contrasts with the observations that giant cell tumors directly promote osteoclast activity via RANKL [212] and our observation that prostate carcinoma cells directly induce osteoclastogenesis through RANKL [76]. Another factor that may play a role in tumorinduced osteoclastogenesis is human macrophage inflammatory protein- $1 \alpha$ (hMIP- $1 \alpha)$, which has been shown to be produced by myeloma cells [213]. Because of the osteoclastic activity induced by many cancers, antiresorptive approaches such as administration of bisphosphonates or anti-PTHrP neutralizing antibody have been reported in breast cancer animal models to be able to block the tumor expansion in bone [214,215].
Furthermore, OPG has been recently shown to inhibit primary bone sarcoma-induced osteolysis and tumorinduced bone pain, but not tumor burden in mice [100]. However, OPG not only blocked osteolytic bone metastasis induced by human neuroblastoma NB-19 cells [216], but also reduced tumor burden in that model. In addition to OPG, a soluble form of RANK (sRANK) has been shown to inhibit myeloma-induced lytic lesions in murine models [217].

\subsection{Matrix metalloproteinases}

Matrix metalloproteinases (MMPs) are family of enzymes whose primary function is to degrade the extracellular matrix. MMPs contribute to metastatic invasion, including destruction of bone [218]. Prostate carcinomas and their cell lines express a large number of MMPs [219-226]. The initial functional data in prostate carcinoma bone metastasis that suggested bone remodeling is modulated through MMPs was provided by in vitro studies. Specifically, blocking MMP activity with 1,10-phenanthroline, a MMP inhibitor, diminished bone matrix degradation induced by PC-3 cells in vitro [227,228]. The importance of MMPs in bone metastasis has been further confirmed in vivo. An MMP inhibitor, batimistat, has been shown to inhibit development bone resorption in vitro and in vivo in murine models of breast [229] and prostate carcinoma [230]. The mechanism through which prostate carcinoma-produced MMPs induce bone resorption is not clear; however, it appears to involve induction of osteoclastogenesis as inhibition of MMPs reduced the number of osteoclasts associated with prostate tumor growth in human bone implants in mice [230].

\section{Conclusions}

A model summarizing the cross-talk between prostate carcinoma and the bone microenvironment that leads to development and progression of prostate carcinoma skeletal metastases is presented in Figure 1. The bone contributes many aspects of the metastatic cascade including chemotaxis, endothelial attachment, invasion and tumor proliferation. Once in the bone microenvironment, the prostate carcinoma cells modulate bone remodeling which favors tumor progression. The presence of many different active factors produced by both the bone and the prostate carcinoma cells that appear to contribute to the pathobiology of skeletal metastases 


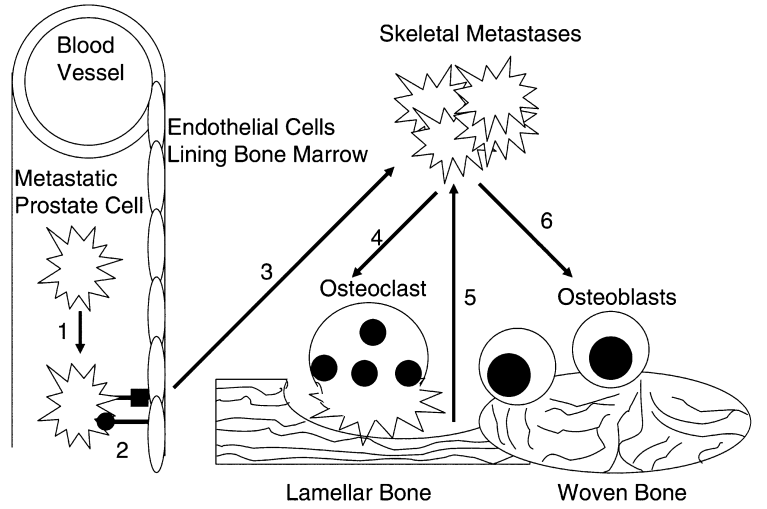

Figure 1. Model of cross-talk between prostate carcinoma cells and the bone microenvironment. The bone produces chemotactic factors that attract prostate carcinoma cells to migrate (1) through the vascular system towards the skeleton. The bone marrow endothelia displays adhesion molecules that complement those expressed by the prostate carcinoma cell, resulting in attachment of the cell (2). The prostate carcinoma cell extravasates and invades into the skeletal extracellular tissue (3), at which point it releases factors that stimulate osteoclastogenesis (4). The subsequent bone resorption is accompanied by release of growth factors that stimulate prostate carcinoma proliferation (5). The progressing prostate carcinoma releases factors that promote osteoblast production and inhibit osteoblast apoptosis (6) resulting in production of woven bone and the characteristic osteosclerotic lesion. This process continues in a cyclical fashion with continued induction of osteoclastic activity, carcinoma cell proliferation and bone production.

suggests that defining the mechanisms of prostate carcinoma skeletal metastases will be challenging. Continued research on how these interactions occur may lead to identification of targets to interrupt this crosstalk and prevent the establishment or progression of prostate cancer skeletal metastases.

\section{Acknowledgements}

This work was supported by USAMRMC Prostate carcinoma Research Program Grant \# DAMD17-00-1053, National Institutes of Health Grants SPORE 1 P50 CA69568 and T32 RR07008.

\section{References}

1. Landis SH, Murray T, Bolden S, Wingo PA: Cancer statistics, 1999. CA Cancer J Clin 49: 8-31, 1999

2. Abrams H, Spiro R, Goldstein N: Metastases in carcinoma Cancer 3: 74-85, 1950
3. Bubendorf L, Schopfer A, Wagner U, Sauter G, Moch H, Willi N, Gasser TC, Mihatsch MJ: Metastatic patterns of prostate cancer: an autopsy study of 1,589 patients. Hum Pathol 31: 578-583, 2000

4. Rana A, Chisholm GD, Khan M, Sekharjit SS, Merrick MV, Elton RA: Patterns of bone metastasis and their prognostic significance in patients with carcinoma of the prostate. $\mathrm{Br} \mathrm{J}$ Urol 72: 933-936, 1993

5. Galasko CS: Skeletal metastases. Clin Orthop 1986: 1830, 1986

6. Coleman RE: Skeletal complications of malignancy. Cancer 80: 1588-1594, 1997

7. Moul JW, Lipo DR: Prostate cancer in the late 1990s: Hormone refractory disease options. Urol Nurs 19: 125-131; quiz 132-123, 1999

8. Szostak MJ, Kyprianou N: Radiation-induced apoptosis: predictive and therapeutic significance in radiotherapy of prostate cancer (review). Oncol Rep 7: 699-706, 2000

9. Papapoulos SE, Hamdy NA, van der Pluijm G: Bisphosphonates in the management of prostate carcinoma metastatic to the skeleton. Cancer 88: 3047-3053, 2000

10. Paget $S$ : The distribution of secondary growth in cancer of the breast. Lancet 1: 571-573, 1829

11. Tsingotjidou AS, Zotalis G, Jackson KR, Sawyers C, Puzas JE, Hicks DG, Reiter R, Lieberman JR: Development of an animal model for prostate cancer cell metastasis to adult human bone. Anticancer Res 21: 971-978, 2001

12. Magro C, Orr FW, Manishen WJ, Sivananthan K, Mokashi SS: Adhesion, chemotaxis, and aggregation of Walker carcinosarcoma cells in response to products of resorbing bone. J Natl Cancer Inst 74: 829-838, 1985

13. Orr W, Varani J, Gondex MK, Ward PA, Mundy GR: Chemotactic responses of tumor cells to products of resorbing bone. Science 203: 176-179, 1979

14. Orr FW, Varani J, Gondek MD, Ward PA, Mundy GR: Partial characterization of a bone-derived chemotactic factor for tumor cells. Am J Pathol 99: 43-52, 1980

15. Wass JA, Varani J, Piontek GE, Ward PA, Orr FW: Responses of normal and malignant cells to collagen, collagen-derived peptides and the C5-related tumor cell chemotactic peptide. Cell Differ 10: 329-332, 1981

16. Jacob K, Webber M, Benayahu D, Kleinman HK: Osteonectin promotes prostate cancer cell migration and invasion: a possible mechanism for metastasis to bone. Cancer Res 59: 4453-4457, 1999

17. Hullinger TG, McCauley LK, DeJoode ML, Somerman MJ: Effect of bone proteins on human prostate cancer cell lines in vitro. Prostate 36: 14-22, 1998

18. Rajan R, Vanderslice R, Kapur S, Lynch J, Thompson R, Djakiew D: Epidermal growth factor (EGF) promotes chemomigration of a human prostate tumor cell line, and EGF immunoreactive proteins are present at sites of metastasis in the stroma of lymph nodes and medullary bone. Prostate 28: 1-9, 1996

19. Somlyo AV, Bradshaw D, Ramos S, Murphy C, Myers CE, Somlyo AP: Rho-kinase inhibitor retards migration and in vivo dissemination of human prostate cancer cells. Biochem Biophys Res Commun 269: 652-659, 2000

20. Baggiolini M: Chemokines and leukocyte traffic. Nature 392: 565-568, 1998 
21. Rossi D, Zlotnik A: The biology of chemokines and their receptors. Annu Rev Immunol 18: 217-242, 2000

22. Strieter RM: Chemokines: Not just leukocyte chemoattractants in the promotion of cancer. Nat Immunol 2: 285-286, 2001

23. Aiuti A, Tavian M, Cipponi A, Ficara F, Zappone E, Hoxie J, Peault B, Bordignon C: Expression of CXCR4, the receptor for stromal cell-derived factor-1 on fetal and adult human lympho-hematopoietic progenitors. Eur J Immunol 29: 1823-1831, 1999

24. Kim CH, Broxmeyer HE: SLC/exodus2/6Ckine/TCA4 induces chemotaxis of hematopoietic progenitor cells: Differential activity of ligands of CCR7, CXCR3, or CXCR4 in chemotaxis vs. suppression of progenitor proliferation. J Leukoc Biol 66: 455-461, 1999

25. Nagasawa $\mathrm{T}$, Hirota $\mathrm{S}$, Tachibana $\mathrm{K}$, Takakura $\mathrm{N}$, Nishikawa S, Kitamura Y, Yoshida N, Kikutani H, Kishimoto T: Defects of B-cell lymphopoiesis and bonemarrow myelopoiesis in mice lacking the $\mathrm{CXC}$ chemokine PBSF/SDF-1. Nature 382: 635-638, 1996

26. Peled A, Petit I, Kollet O, Magid M, Ponomaryov T, Byk T, Nagler A, Ben-Hur H, Many A, Shultz L, Lider O, Alon R, Zipori D, Lapidot T: Dependence of human stem cell engraftment and repopulation of NOD/SCID mice on CXCR4. Science 283: 845-848, 1999

27. Ponomaryov T, Peled A, Petit I, Taichman RS, Habler L, Sandbank J, Arenzana-Seisdedos F, Magerus A, Caruz A, Fujii N, Nagler A, Lahav M, Szyper-Kravitz M, Zipori $\mathrm{D}$, Lapidot T: Induction of the chemokine stromal-derived factor-1 following DNA damage improves human stem cell function. J Clin Invest 106: 1331-1339, 2000

28. Imai K, Kobayashi M, Wang J, Shinobu N, Yoshida $\mathrm{H}$, Hamada J, Shindo M, Higashino F, Tanaka J, Asaka M, Hosokawa M: Selective secretion of chemoattractants for haemopoietic progenitor cells by bone marrow endothelia cells: a possible role in homing of haemopoietic progenitor cells to bone marrow. Br J Haematol 106: 905-911, 1999

29. Moore BB, Arenberg DA, Stoy K, Morgan T, Addison CL, Morris SB, Glass M, Wilke C, Xue YY, Sitterding S, Kunkel SL, Burdick MD, Strieter RM: Distinct CXC chemokines mediate tumorigenicity of prostate cancer cells. Am J Pathol 154: 1503-1512, 1999

30. Reiland J, Furcht LT, McCarthy JB: CXC-chemokines stimulate invasion and chemotaxis in prostate carcinoma cells through the CXCR2 receptor. Prostate 41: 78-88, 1999

31. Gupta SK, Pillarisetti K: Cutting edge: CXCR4-Lo: Molecular cloning and functional expression of a novel human CXCR4 splice variant. J Immunol 163: 2368-2372, 1999

32. Sehgal A, Ricks S, Boynton AL, Warrick J, Murphy GP: Molecular characterization of CXCR-4: A potential brain tumor-associated gene. J Surg Oncol 69: 239-248, 1998

33. Mohle R, Failenschmid C, Bautz F, Kanz L: Overexpression of the chemokine receptor CXCR4 in $\mathrm{B}$ cell chronic lymphocytic leukemia is associated with increased functional response to stromal cell-derived factor-1 (SDF-1). Leukemia 13: 1954-1959, 1999
34. Taichman R, McCauley L, Taichman N: Use of the SDF-1/CXCR4 pathway in prostate cancer metastasis to bone. Blood 96: 571a, 2000

35. Muller C, Homey B, Sato H, Ge N, Catron D, Buchanan M, McClanahan T, Murphy E, Yuan W, Wagners S, Barrera J, Mohar A, Verastegui E, Zlotnik A: Involvement of chemokine receptors in breast cancer metastasis. Nature 410: 50-56, 2001

36. Liotta LA: An attractive force in metastasis. Nature 410 : 24-25, 2001

37. Miyasaka M: Cancer metastasis and adhesion molecules. Clin Orthop 312: 10-18, 1995

38. Orr FW, Wang HH, Lafrenie RM, Scherbarth S, Nance DM: Interactions between cancer cells and the endothelium in metastasis. J Pathol 190: 310-329, 2000

39. Pauli BU, Augustin-Voss HG, El-Sabban ME, Johnson RC, Hammer DA: Organ-preference of metastasis. Cancer and Metastasis Rev 9: 175-189, 1990

40. Deroock IB, Pennington ME, Sroka TC, Lam KS, Bowden GT, Bair EL, Cress AE: Synthetic peptides inhibit adhesion of human tumor cells to extracellular matrix proteins. Cancer Res 61: 3308-3313, 2001

41. vanderPluijm G, Vloedgraven H, Papapoulos S, Lowik C, Grzesik W, Kerr J, Robey PG: Attachment characteristics and involvement of integrins in adhesion of breast cancer cell lines to extracellular bone matrix components. Lab Inves 77: 665-675, 1997

42. Lehr JE, Pienta KJ: Preferential adhesion of prostate cancer cells to a human bone marrow endothelial cell line (see comments). J Natl Cancer Inst 90: 118-123, 1998

43. Cooper CR, Pienta KJ: Cell adhesion and chemotaxis in prostate cancer metastasis to bone: a minireview. Prostate Canc Prostatic Dis 3: 6-12, 2000

44. Cooper CR, Mclean L, Walsh M, Taylor J, Hayasaka S, Bhatia J, Pienta KJ: Preferential adhesion to prostate cancer cells to bone is mediated by binding to bone marrow endothelial cells as compared to extracellular matrix components in vitro. Clin Cancer Res 6: 4839-4847, 2000

45. Scott LJ, Clarke NW, George NJ, Shanks JH, Testa NG, Lang SH: Interactions of human prostatic epithelial cells with bone marrow endothelium: binding and invasion. $\mathrm{Br} \mathrm{J}$ Cancer 84: 1417-1423, 2001

46. Pienta KJ, Naik H, Akhtar A, Yamazaki K, Replogle TS, Lehr J, Donat TL, Tait L, Hogan V, Raz A: Inhibition of spontaneous metastasis in a rat prostate cancer model by oral administration of modified citrus pectin. J Natl Cancer Inst 87: 348-353, 1995

47. Romanov VI, Goligorsky MS: RGD-recognizing integrins mediate interactions of human prostate carcinoma cells with endothelial cells in vitro. Prostate 39: 108-118, 1999

48. Cooper CR, McLean L, Mucci NR, Poncza P, Pienta KJ: Prostate cancer cell adhesion to quiescent endothelial cells is not mediated by beta- 1 integrin subunit. Anticancer Res 20: 4159-4162, 2000

49. Simpson MA, Reiland J, Burger SR, Furch LT, Spice AP, Theodore R. Oegema J, McCarthy JB: Hyaluronan synthase elevation in metastatic prostate carcinoma cells correlates with hyaluronan surface retention, a prerequisite for 
rapid adhesion to bone marrow endothelial cells. J Biol Chem 276: 17949-17957, 2001

50. Kierszenbaum AL, Rivkin E, Chang PL, Tres LL, Olsson CA: Galactosyl receptor, a cell surface C-type lectin of normal and tumoral prostate epithelial cells with binding affinity to endothelial cells. Prostate 43: 175-183, 2000

51. Kostenuik PJ, Sanchez-Sweatman O, Orr FW, Singh G: Bone cell matrix promotes the adhesion of human prostatic carcinoma cells via the alpha 2 beta 1 integrin. Clin Exp Metastasis 14: 19-26, 1996

52. Festuccia C, Bologna M, Gravina GL, Guerra F, Angelucci A, Villonava I, Millimaggi D, Teti A: Osteoblast conditioned media contained TGF-betal and modulat the migration of prostate tumor cells and their interactions with extracellular matrix components. Int J Cancer 81:395-403, 1999

53. Kostenuik PJ, Singh G, Orr FW: Transforming growth factor-beta upregulates the integrin-mediated adhesion of human prostatic carcinoma cells to type I collagen. Clin Exp Metastasis 15: 41-52, 1997

54. Martinez J, Fuentes M, Cambiazo V, Santibanez JF: Bone extracellular matrix stimulates invasiveness of estrogenresponsive human mammary MCF-7 cells. Int J Cancer 83: 278-282, 1999

55. Linkhart TA, Mohan S, Baylink DJ: Growth factors for bone growth and repair: IGF, TGF beta and BMP. Bone 19 1S-12S, 1996

56. Manishen WJ, Sivananthan K, Orr FW: Resorbing bone stimulates tumor cell growth. A role for the host microenvironment in bone metastasis. Am J Pathol 123: 39-45, 1986

57. Ritchie CK, Andrews LR, Thomas KG, Tindall DJ, Fitzpatrick LA: The effects of growth factors associated with osteoblasts on prostate carcinoma proliferation and chemotaxis: Implications for the development of metastatic disease. Endocrinology 138: 1145-1150, 1997

58. Song Z, Powell WC, Kasahara N, van Bokhoven A, Miller GJ, Roy-Burman P: The effect of fibroblast growth factor 8 , isoform $b$, on the biology of prostate carcinoma cells and their interaction with stromal cells. Cancer Res 60: 6730-6736, 2000

59. Desruisseau S, Ghazarossian-Ragni E, Chinot O Martin PM: Divergent effect of TGFbetal on growth and proteolytic modulation of human prostatic-cancer cell lines. Int J Cancer 66: 796-801, 1996

60. Djavan B, Waldert M, Seitz C, Marberger M: Insulinlike growth factors and prostate cancer. World J Urol 19: 225-233, 2001

61. Peehl DM, Cohen P, Rosenfeld RG: The insulin-like growth factor system in the prostate. World J Urol 13: 306-311, 1995

62. Cohen P, Peehl DM, Lamson G, Rosenfeld RG: Insulin-like growth factors (IGFs), IGF receptors, and IGF-binding proteins in primary cultures of prostate epithelial cells. J Clin Endocrinol Metab 73: 401-407, 1991

63. Festuccia C, Giunciuglio D, Guerra F, Villanova I, Angelucci A, Manduca P, Teti A, Albini A, Bologna M: Osteoblasts modulate secretion of urokinase-type plasminogen activator (UPA) and matrix metalloproteinase- 9
(MMP-9) in human prostate cancer cells promoting migration and matrigel invasion. Oncol Res 11: 17-31, 1999

64. Lang SH, Clarke NW, George NJ, Allen TD, Testa NG: Interaction of prostate epithelial cells from benign and malignant tumor tissue with bone-marrow stroma. Prostate 34: 203-213, 1998

65. Gleave ME, Hsieh JT, von Eschenbach AC, Chung LW: Prostate and bone fibroblasts induce human prostate cancer growth in vivo: Implications for bidirectional tumorstromal cell interaction in prostate carcinoma growth and metastasis. J Urol 147: 1151-1159, 1992

66. Gleave M, Hsieh JT, Gao CA, von Eschenbach AC, Chung LW: Acceleration of human prostate cancer growth in vivo by factors produced by prostate and bone fibroblasts. Cancer Res 51: 3753-3761, 1991

67. Yamashita K, Aoki Y, Hiroshima K: Metastatic epidural bony tumor causing spinal cord compression: A case report. Clin Orthop 1996: 231-235, 1996

68. Munk PL, Poon PY, O'Connell JX, Janzen D, Coupland D, Kwong JS, Gelmon K, Worsley D: Osteoblastic metastases from breast carcinoma with false-negative bone scan. Skeletal Radiol 26: 434-437, 1997

69. Berruti A, Piovesan A, Torta M, Raucci CA, Gorzegno G, Paccotti P, Dogliotti L, Angeli A: Biochemical evaluation of bone turnover in cancer patients with bone metastases: Relationship with radiograph appearances and disease extension. Br J Cancer 73: 1581-1587, 1996

70. Vinholes J, Coleman R, Eastell R: Effects of bone metastases on bone metabolism: Implications for diagnosis, imaging and assessment of response to cancer treatment. Cancer Treat Rev 22: 289-331, 1996

71. Urwin GH, Percival RC, Harris S, Beneton MN, Williams JL, Kanis JA: Generalised increase in bone resorption in carcinoma of the prostate. Br J Urol 57: 721-723, 1985

72. Roudier M, Sherrard D, True L, Ott-Ralp S, Meligro C, MBerrie M, Soo C, Felise D, Quinn JE, Vessella R: Heterogenous bone histomorphometric patterns in metastatic prostate cancer. J Bone Miner Res 15S1: S567, 2000

73. Clarke NW, McClure J, George NJ: Osteoblast function and osteomalacia in metastatic prostate cancer. Eur Urol 24: 286-290, 1993

74. Charhon SA, Chapuy MC, Delvin EE, Valentin-Opran A, Edouard CM, Meunier PJ: Histomorphometric analysis of sclerotic bone metastases from prostatic carcinoma special reference to osteomalacia. Cancer 51: 918-924, 1983

75. Carlin BI, Andriole GL: The natural history, skeletal complications, and management of bone metastases in patients with prostate carcinoma. Cancer 88: 2989-2994, 2000

76. Zhang J, Dai J, Qi Y, Lin DL, Smith P, Strayhorn C, Mizokami A, Fu Z, Westman J, Keller ET: Osteoprotegerin inhibits prostate cancer-induced osteoclastogenesis and prevents prostate tumor growth in the bone. J Clin Invest 107: 1235-1244, 2001

77. Maeda H, Koizumi M, Yoshimura K, Yamauchi T, Kawai T, Ogata E: Correlation between bone metabolic markers and bone scan in prostatic cancer. J Urol 157: 539-543, 1997 
78. Demers LM, Costa L, Lipton A: Biochemical markers and skeletal metastases. Cancer 88: 2919-2926, 2000

79. Karsenty G: Bone formation and factors affecting this process. Matrix Biol 19: 85-89, 2000

80. Parfitt AM: The mechanism of coupling: A role for the vasculature. Bone 26: 319-323, 2000

81. Boyce BF, Hughes DE, Wright KR, Xing L, Dai A: Recent advances in bone biology provide insight into the pathogenesis of bone diseases. Lab Invest 79: 83-94, 1999

82. Rosol TJ: Pathogenesis of bone metastases: Role of tumorrelated proteins. J Bone Miner Res 15: 844-850, 2000

83. Blomme EA, Dougherty KM, Pienta KJ, Capen CC, Rosol TJ, McCauley LK: Skeletal metastasis of prostate adenocarcinoma in rats: Morphometric analysis and role of parathyroid hormone-related protein. Prostate 39: 187-197, 1999

84. Yang J, Fizazi K, Peleg S, Sikes CR, Raymond AK, Jamal N, Hu M, Olive M, Martinez LA, Wood CG, Logothetis CJ, Karsenty G, Navone NM: Prostate cancer cells induce osteoblast differentiation through a Cbfa1dependent pathway. Cancer Res 61: 5652-5659, 2001

85. Lin DL, Tarnowski CP, Zhang J, Dai J, Rohn E, Patel AH, Morris MD, Keller ET: Bone metastatic LNCaP-derivative C4-2B prostate cancer cell line mineralizes in vitro. Prostate 47: 212-221, 2001

86. Boyce BF, Yoneda T, Guise TA: Factors regulating the growth of metastatic cancer in bone. Endocr Relat Cancer 6: 333-347, 1999

87. Deftos LJ: Prostate carcinoma: Production of bioactive factors. Cancer 88: 3002-3008, 2000

88. Yoneda T: Cellular and molecular mechanisms of breas and prostate cancer metastasis to bone. Eur J Cancer 34 240-245, 1998

89. Goltzman D, Bolivar I, Rabbani SA: Studies on the pathogenesis of osteoblastic metastases by prostate cancer. Adv Exp Med Biol 324: 165-171, 1992

90. Koutsilieris M, Rabbani SA, Goltzman D: Selective osteoblast mitogens can be extracted from prostatic tissue. Prostate 9: 109-115, 1986

91. Autzen P, Robson CN, Bjartell A, Malcolm AJ, Johnson MI, Neal DE, Hamdy FC: Bone morphogenetic protein 6 in skeletal metastases from prostate cancer and other common human malignancies. Br $\mathrm{J}$ Cancer 78 : 1219-1223, 1998

92. Harris SE, Harris MA, Mahy P, Wozney J, Feng JQ, Mundy GR: Expression of bone morphogenetic protein messenger RNAs by normal rat and human prostate and prostate cancer cells. Prostate 24: 204-211, 1994

93. Hullinger TG, Taichman RS, Linseman DA, Somerman MJ: Secretory products from PC-3 and MCF-7 tumor cell lines upregulate osteopontin in MC3T3-E1 cells. J Cell Biochem 78: 607-616, 2000

94. Nelson JB, Hedican SP, George DJ, Reddi AH, Piantadosi S, Eisenberger MA, Simons JW: Identification of endothelin-1 in the pathophysiology of metastatic adenocarcinoma of the prostate. Nat Med 1: 944-949, 1995

95. Kimura G, Sugisaki Y, Masugi Y, Nakazawa N: Calcification in human osteoblasts cultured in medium conditioned by the prostatic cancer cell line PC-3 and prostatic acid phosphatase. Urol Int 48: 25-30, 1992
96. Karaplis AC, Vautour L: Parathyroid hormone-related peptide and the parathyroid hormone/parathyroid hormonerelated peptide receptor in skeletal development. Curr Opin Nephrol Hypertens 6: 308-313, 1997

97. Cornish J, Callon KE, Lin C, Xiao C, Moseley JM, Reid IR: Stimulation of osteoblast proliferation by C-terminal fragments of parathyroid hormone-related protein. J Bone Miner Res 14: 915-922, 1999

98. Rabbani SA, Gladu J, Mazar AP, Henkin J, Goltzman D: Induction in human osteoblastic cells $(\mathrm{SaOS} 2)$ of the early response genes fos, jun, and myc by the amino terminal fragment (ATF) of urokinase. J Cell Physiol 172: 137-145, 1997

99. Killian CS, Corral DA, Kawinski E, Constantine RI: Mitogenic response of osteoblast cells to prostate-specific antigen suggests an activation of latent TGF-beta and a proteolytic modulation of cell adhesion receptors. Biochem Biophys Res Commun 192: 940-947, 1993

100. Honore P, Luger NM, Sabino MA, Schwei MJ, Rogers SD, Mach DB, O'Keefe PF, Ramnaraine ML, Clohisy DR, Mantyh PW: Osteoprotegerin blocks bone cancer-induced skeletal destruction, skeletal pain and pain-related neurochemical reorganization of the spinal cord. Nat Med 6: 521-528, 2000

101. Guise TA: Molecular mechanisms of osteolytic bone metastases. Cancer 88: 2892-2898, 2000

102. Simonet WS, Lacey DL, Dunstan CR, Kelley M, Chang MS, Luthy R, Nguyen HQ, Wooden S, Bennett L, Boone T, Shimamoto G, DeRose M, Elliott R, Colombero A, Tan HL, Trail G, Sullivan J, Davy E, Bucay N, Renshaw-Gegg L, Hughes TM, Hill D, Pattison W, Campbell P, Boyle WJ: Osteoprotegerin: A novel secreted protein involved in the regulation of bone density. Cell 89: 309-319, 1997

103. Chiao JW, Moonga BS, Yang YM, Kancherla R, Mittelman A, Wu-Wong JR, Ahmed T: Endothelin-1 from prostate cancer cells is enhanced by bone contact which blocks osteoclastic bone resorption. $\mathrm{Br} \mathrm{J}$ Cancer 83: 360-365, 2000

104. Laitinen M, Marttinen A, Aho AJ, Lindholm TS: Bone morphogenetic protein in bone neoplasms: Comparison of different detection methods. Eur Surg Res 30: 168-174, 1998

105. Raval P, Hsu HH, Schneider DJ, Sarras MP Jr., Masuhara K, Bonewald LF, Anderson HC: Expression of bone morphogenetic proteins by osteoinductive and non-osteoinductive human osteosarcoma cells. J Dent Res 75: 1518-1523, 1996

106. Wlosarski $\mathrm{K}$, Reddi AH: Tumor cells stimulate in vivo periosteal bone formation. Bone Miner 2: 185-192, 1987

107. Strewler GJ: The physiology of parathyroid hormonerelated protein. N Engl J Med 342: 177-185, 2000

108. Lanske B, Amling M, Neff L, Guiducci J, Baron R, Kronenberg HM: Ablation of the PTHrP gene or the $\mathrm{PTH} / \mathrm{PTHrP}$ receptor gene leads to distinct abnormalities in bone development. J Clin Invest 104: 399-407, 1999

109. Amizuka N, Henderson JE, White JH, Karaplis AC, Goltzman D, Sasaki T, Ozawa H: Recent studies on the biological action of parathyroid hormone (PTH)-related 
peptide (PTHrP) and $\mathrm{PTH} / \mathrm{PTHrP}$ receptor in cartilage and bone. Histol Histopathol 15: 957-970, 2000

110. Iwamura M, Abrahamsson PA, Schoen S, Cockett AT, Deftos LJ: Immunoreactive parathyroid hormone-related protein is present in human seminal plasma and is of prostate origin. J Androl 15: 410-414, 1994

111. Iwamura M, di Sant'Agnese PA, Wu G, Benning CM, Cockett AT, Deftos LJ, Abrahamsson PA: Immunohistochemical localization of parathyroid hormone-related protein in human prostate cancer. Cancer Res 53: 1724-1726, 1993

112. Asadi F, Farraj M, Sharifi R, Malakouti S, Antar S, Kukreja S: Enhanced expression of parathyroid hormonerelated protein in prostate cancer as compared with benign prostatic hyperplasia. Hum Pathol 27: 1319-1323, 1996

113. Iwamura $\mathrm{M}$, Gershagen $\mathrm{S}$, Lapets $\mathrm{O}$, Moynes $\mathrm{R}$, Abrahamsson PA, Cockett AT, Deftos LJ, di Sant'Agnese PA: Immunohistochemical localization of parathyroid hormone-related protein in prostatic intraepithelial neoplasia. Hum Pathol 26: 797-801, 1995

114. Dougherty KM, Blomme EA, Koh AJ, Henderson JE, Pienta KJ, Rosol TJ, McCauley LK: Parathyroid hormonerelated protein as a growth regulator of prostate carcinoma. Cancer Res 59: 6015-6022, 1999

115. Burton PB, Moniz C, Knight DE: Parathyroid hormone related peptide can function as an autocrine growth factor in human renal cell carcinoma. Biochem Biophys Res Commun 167: 1134-1138, 1990

116. Bouizar Z, Spyratos F, De vernejoul MC: The parathyroid hormone-related protein (PTHrP) gene: use of downstream TATA promotor and PTHrP 1-139 coding pathways in primary breast cancers vary with the occurrence of bone metastasis. J Bone Miner Res 14: 406-414, 1999

117. Yin JJ, Selander K, Chirgwin JM, Dallas M, Grubbs BG, Wieser R, Massague J, Mundy GR, Guise TA: TGF-beta signaling blockade inhibits PTHrP secretion by breast cancer cells and bone metastases development. J Clin Invest 103: 197-206, 1999

118. Iwamura M, Abrahamsson PA, Foss KA, Wu G Cockett AT, Deftos LJ: Parathyroid hormone-related protein: a potential autocrine growth regulator in human prostate cancer cell lines. Urology 43: 675-679, 1994

119. Henderson JE, Amizuka N, Warshawsky H, Biasotto D, Lanske BM, Goltzman D, Karaplis AC: Nucleolar localization of parathyroid hormone-related peptide enhances survival of chondrocytes under conditions that promote apoptotic cell death. Mol Cell Biol 15: 4064-4075, 1995

120. Aarts MM, Levy D, He B, Stregger S, Chen T, Richard S, Henderson JE: Parathyroid hormone-related protein interacts with RNA. J Biol Chem 274: 4832-4838, 1999

121. Ye Y, Falzon M, Seitz PK, Cooper CW: Overexpression of parathyroid hormone-related protein promotes cel growth in the rat intestinal cell line IEC-6. Regul Pept 99: 169-174, 2001

122. Massfelder T, Dann P, Wu TL, Vasavada R, Helwig JJ, Stewart AF: Opposing mitogenic and anti-mitogenic actions of parathyroid hormone-related protein in vascular smooth muscle cells: a critical role for nuclear targeting. Proc Natl Acad Sci USA 94: 13630-13635, 1997
123. Cramer SD, Chen Z, Peehl DM: Prostate specific antigen cleaves parathyroid hormone-related protein in the PTHlike domain: Inactivation of PTHrP-stimulated cAMP accumulation in mouse osteoblasts. J Urol 156: 526-531, 1996

124. Ye Y, Seitz PK, Cooper CW: Parathyroid hormone-related protein overexpression in the human colon cancer cell line HT-29 enhances adhesion of the cells to collagen type I. Regul Pept 101: 19-23, 2001

125. Stjernquist $\mathrm{M}$ : Endothelins-vasoactive peptides and growth factors. Cell Tissue Res 292: 1-9, 1998

126. Takuwa Y, Ohue Y, Takuwa N, Yamashita K: Endothelin-1 activates phospholipase $\mathrm{C}$ and mobilizes $\mathrm{Ca}^{2+}$ from extraand intracellular pools in osteoblastic cells. Am J Physiol 257: E797-803, 1989

127. Hiruma Y, Inoue A, Shiohama A, Otsuka E, Hirose S, Yamaguchi A, Hagiwara $\mathrm{H}$ : Endothelins inhibit the mineralization of osteoblastic MC3T3-E1 cells through the A-type endothelin receptor. Am J Physiol 275: R1099-1105, 1998

128. Zaidi M, Alam AS, Bax BE, Shankar VS, Bax CM, Gill JS, Pazianas M, Huang CL, Sahinoglu T, Moonga BS, et al.: Role of the endothelial cell in osteoclast control: New perspectives. Bone 14: 97-102, 1993

129. Tatrai A, Foster S, Lakatos P, Shankar G, Stern PH: Endothelin-1 actions on resorption, collagen and noncollagen protein synthesis, and phosphatidylinositol turnover in bone organ cultures. Endocrinology 131: 603-607, 1992

130. Shioide M, Noda M: Endothelin modulates osteopontin and osteocalcin messenger ribonucleic acid expression in rat osteoblastic osteosarcoma cells. J Cell Biochem 53: 176-180, 1993

131. Kasperk CH, Borcsok I, Schairer HU, Schneider U, Nawroth PP, Niethard FU, Ziegler R: Endothelin-1 is a potent regulator of human bone cell metabolism in vitro. Calcif Tissue Int 60: 368-374, 1997

132. Tsukahara H, Hori C, Hiraoka M, Yamamoto K, Ishii Y, Mayumi M: Endothelin subtype A receptor antagonist induces osteopenia in growing rats. Metabolism 47: 1403-1407, 1998

133. Langenstroer P, Tang R, Shapiro E, Divish B, Opgenorth T, Lepor H: Endothelin-1 in the human prostate: Tissue levels, source of production and isometric tension studies. J Urol 150: 495-499, 1993

134. Walden PD, Ittmann M, Monaco ME, Lepor H: Endothelin1 production and agonist activities in cultured prostatederived cells: Implications for regulation of endothelin bioactivity and bioavailability in prostatic hyperplasia. Prostate 34: 241-250, 1998

135. Casey ML, Byrd W, MacDonald PC: Massive amounts of immunoreactive endothelin in human seminal fluid. J Clin Endocrinol Metab 74: 223-225, 1992

136. Nelson JB, Carducci MA: The role of endothelin-1 and endothelin receptor antagonists in prostate cancer. BJU Int 85(Suppl 2): 45-48, 2000

137. Nelson JB, Nguyen SH, Wu-Wong JR, Opgenorth TJ, Dixon DB, Chung LW, Inoue N: New bone formation in an osteoblastic tumor model is increased by endothelin-1 
overexpression and decreased by endothelin A receptor blockade. Urology 53: 1063-1069, 1999

138. Yin J, Grubbs B, Cui Y, Weu-Wong J, Wessale J, Padley R, Guise T: Endothelin A receptor blockade inhibits osteoblastic metastases. J Bone Miner Res 15: S201, 2000

139. Tarquini R, Perfetto F, Tarquini B: Endothelin-1 and Paget's bone disease: Is there a link? Calcif Tissue Int 63 : 118-120, 1998

140. Ducy P, Karsenty G: The family of bone morphogenetic proteins. Kidney Int 57: 2207-2214, 2000

141. Reddi AH: Bone morphogenetic proteins: An unconventional approach to isolation of first mammalian morphogens. Cytokine Growth Factor Rev 8: 11-20, 1997

142. Hogan BL: Bone morphogenetic proteins in development. Curr Opin Genet Dev 6: 432-438, 1996

143. Hall BK, Miyake T: All for one and one for all: condensations and the initiation of skeletal development. Bioessays 22: $138-147,2000$

144. Wozney JM: The bone morphogenetic protein family and osteogenesis. Mol Reprod Dev 32: 160-167, 1992

145. Suzuki A, Kaneko E, Maeda J, Ueno N: Mesoderm induction by BMP- 4 and -7 heterodimers. Biochem Biophys Res Commun 232: 153-156, 1997

146. Wrana JL: Regulation of Smad activity. Cell 100: 189-192, 2000

147. Wan M, Shi X, Feng X, Cao X: Transcriptional mechanisms of bone morphogenetic protein induced osteoprotegrin gene expression. J Biol Chem 276: 10119-10125, 2001

148. Tsuji K, Ito Y, Noda M: Expression of the PEBP2alphaA/AML3/CBFA1 gene is regulated by BMP4/7 heterodimer and its overexpression suppresses type I collagen and osteocalcin gene expression in osteoblastic and nonosteoblastic mesenchymal cells. Bone 22: 87-92, 1998

149. Gori F, Thomas T, Hicok KC, Spelsberg TC, Riggs BL: Differentiation of human marrow stromal precursor cells: Bone morphogenetic protein-2 increases OSF2/CBFA1, enhances osteoblast commitment, and inhibits late adipocyte maturation. J Bone Miner Res 14: 1522-1535, 1999

150. Abe E, Yamamoto M, Taguchi Y, Lecka-Czernik B, O'Brien CA, Economides AN, Stahl N, Jilka RL, Manolagas SC: Essential requirement of BMPs-2/4 for both osteoblast and osteoclast formation in murine bone marrow cultures from adult mice: antagonism by noggin. J Bone Miner Res 15: 663-673, 2000

151. Zimmerman LB, De Jesus-Escobar JM, Harland RM: The Spemann organizer signal noggin binds and inactivates bone morphogenetic protein 4. Cell 86: 599-606, 1996

152. Merino R, Rodriguez-Leon J, Macias D, Ganan Y, Economides AN, Hurle JM: The BMP antagonist Gremlin regulates outgrowth, chondrogenesis and programmed cell death in the developing limb. Development 126 : 5515-5522, 1999

153. Nifuji A, Noda M: Coordinated expression of noggin and bone morphogenetic proteins (BMPs) during early skeletogenesis and induction of noggin expression by BMP-7. J Bone Miner Res 14: 2057-2066, 1999
154. Nifuji A, Kellermann O, Noda M: Noggin expression in a mesodermal pluripotent cell line $\mathrm{C} 1$ and its regulation by BMP. J Cell Biochem 73: 437-444, 1999

155. Li IW, Cheifetz S, McCulloch CA, Sampath KT, Sodek J: Effects of osteogenic protein-1 (OP-1, BMP-7) on bone matrix protein expression by fetal rat calvarial cells are differentiation stage specific. J Cell Physiol 169: 115-125, 1996

156. Asahina I, Sampath TK, Nishimura I, Hauschka PV: Human osteogenic protein-1 induces both chondroblastic and osteoblastic differentiation of osteoprogenitor cells derived from newborn rat calvaria. J Cell Biol 123: 921-933, 1993

157. Maliakal JC, Asahina I, Hauschka PV, Sampath TK: Osteogenic protein-1 (BMP-7) inhibits cell proliferation and stimulates the expression of markers characteristic of osteoblast phenotype in rat osteosarcoma (17/2.8) cells. Growth Factors 11: 227-234, 1994

158. Yamaguchi A, Ishizuya T, Kintou N, Wada Y, Katagiri T, Wozney JM, Rosen V, Yoshiki S: Effects of BMP-2, BMP-4, and BMP-6 on osteoblastic differentiation of bone marrow-derived stromal cell lines, ST2 and MC3T3G2/PA6. Biochem Biophys Res Commun 220: 366-371, 1996

159. Katagiri T, Yamaguchi A, Ikeda T, Yoshiki S, Wozney JM, Rosen V, Wang EA, Tanaka H, Omura S, Suda T: The non-osteogenic mouse pluripotent cell line, C3H10T1/2, is induced to differentiate into osteoblastic cells by recombinant human bone morphogenetic protein-2. Biochem Biophys Res Commun 172: 295-299, 1990

160. Katagiri T, Akiyama S, Namiki M, Komaki M, Yamaguchi A, Rosen V, Wozney JM, Fujisawa-Sehara A, Suda T: Bone morphogenetic protein-2 inhibits terminal differentiation of myogenic cells by suppressing the transcriptional activity of MyoD and myogenin. Exp Cell Res 230: 342-351, 1997

161. Ducy P, Schinke T, Karsenty G: The osteoblast: A sophisticated fibroblast under central surveillance. Science 289: 1501-1504, 2000

162. Knutsen R, Wergedal JE, Sampath TK, Baylink DJ, Mohan S: Osteogenic protein-1 stimulates proliferation and differentiation of human bone cells in vitro. Biochem Biophys Res Commun 194: 1352-1358, 1993

163. Kim KJ, Itoh T, Kotake S: Effects of recombinant human bone morphogenetic protein- 2 on human bone marrow cells cultured with various biomaterials. J Biomed Mater Res 35: 279-285, 1997

164. Groeneveld EH, Burger EH: Bone morphogenetic proteins in human bone regeneration. Eur J Endocrinol 142: 9-21, 2000

165. Jena N, Martin-Seisdedos C, McCue P, Croce CM: BMP7 null mutation in mice: Developmental defects in skeleton, kidney, and eye. Exp Cell Res 230: 28-37, 1997

166. Solloway MJ, Dudley AT, Bikoff EK, Lyons KM, Hogan BL, Robertson EJ: Mice lacking Bmp6 function. Dev Genet 22: 321-339, 1998

167. Kingsley DM, Bland AE, Grubber JM, Marker PC, Russell LB, Copeland NG, Jenkins NA: The mouse short ear skeletal morphogenesis locus is associated with defects 
in a bone morphogenetic member of the TGF beta superfamily. Cell 71: 399-410, 1992

168. Weber KL, Bolander ME, Rock MG, Pritchard D, Sarkar G Evidence for the upregulation of osteogenic protein-1 mRNA expression in musculoskeletal neoplasms. J Orthop Res 16: 8-14, 1998

169. Bentley H, Hamdy FC, Hart KA, Seid JM, Williams JL, Johnstone D, Russell RG: Expression of bone morphogenetic proteins in human prostatic adenocarcinoma and benign prostatic hyperplasia. Br J Cancer 66: 1159-1163, 1992

170. Barnes J, Anthony CT, Wall N, Steiner MS: Bone morphogenetic protein- 6 expression in normal and malignant prostate. World J Urol 13: 337-343, 1995

171. Hamdy FC, Autzen P, Robinson MC, Horne CH, Neal DE, Robson CN: Immunolocalization and messenger RNA expression of bone morphogenetic protein- 6 in human benign and malignant prostatic tissue. Cancer Res 57: 4427-4431, 1997

172. Kim IY, Lee DH, Ahn HJ, Tokunaga H, Song W, Devereaux LM, Jin D, Sampath TK, Morton RA: Expression of bone morphogenetic protein receptors type-IA, -IB and -II correlates with tumor grade in human prostate cancer tissues. Cancer Res 60: 2840-2844, 2000

173. Ide H, Katoh M, Sasaki H, Yoshida T, Aoki K, Nawa Y, Osada Y, Sugimura T, Terada M: Cloning of human bone morphogenetic protein type IB receptor (BMPR-IB) and its expression in prostate cancer in comparison with other BMPRs (published erratum appears in Oncogene 1997 Aug 28;15(9):1121). Oncogene 14: 1377-1382, 1997

174. Ide H, Yoshida T, Matsumoto N, Aoki K, Osada Y, Sugimura T, Terada M: Growth regulation of human prostate cancer cells by bone morphogenetic protein- 2 . Cancer Res 57: 5022-5027, 1997

175. Mundy GR, Yoneda T, Hiraga T: Preclinical studies with zoledronic acid and other bisphosphonates: Impact on the bone microenvironment. Semin Oncol 28: 35-44, 2001

176. Theriault RL, Hortobagyi GN: The evolving role of bisphosphonates. Semin Oncol 28: 284-290, 2001

177. Pelger RC, Hamdy NA, Zwinderman AH, Lycklama a Nijeholt AA, Papapoulos SE: Effects of the bisphosphonate olpadronate in patients with carcinoma of the prostate metastatic to the skeleton. Bone 22: 403-408, 1998

178. Garnero P, Buchs N, Zekri J, Rizzoli R, Coleman RE, Delmas PD: Markers of bone turnover for the management of patients with bone metastases from prostate cancer. $\mathrm{Br}$ J Cancer 82: 858-864, 2000

179. Heidenreich A, Hofmann R, Engelmann UH: The use of bisphosphonate for the palliative treatment of painful bone metastasis due to hormone refractory prostate cancer (In Process Citation). J Urol 165: 136-140, 2001

180. Stearns ME, Wang M: Effects of alendronate and taxol on PC-3 ML cell bone metastases in SCID mice. Inv Met 16: 116-131, 1996

181. Sun YC, Geldof AA, Newling DW, Rao BR: Progression delay of prostate tumor skeletal metastasis effects by bisphosphonates. J Urol 148: 1270-1273, 1992
182. Wang M, Stearns ME: Isolation and characterization of PC-3 human prostatic tumor sublines which preferentially metastasize to select organs in S.C.I.D. mice. Differentiation 48: 115-125, 1991

183. Boissier S, Ferreras M, Peyruchaud O, Magnetto S, Ebetino FH, Colombel M, Delmas P, Delaisse JM, Clezardin P: Bisphosphonates inhibit breast and prostate carcinoma cell invasion, an early event in the formation of bone metastases. Cancer Res 60: 2949-2954, 2000

184. Boissier S, Magnetto S, Frappart L, Cuzin B, Ebetino FH, Delmas PD, Clezardin P: Bisphosphonates inhibit prostate and breast carcinoma cell adhesion to unmineralized and mineralized bone extracellular matrices. Cancer Res 57: 3890-3894, 1997

185. Lee MV, Fong EM, Singer FR, Guenette RS: Bisphosphonate treatment inhibits the growth of prostate cancer cells. Cancer Res 61: 2602-2608, 2001

186. Diel IJ: Antitumour effects of bisphosphonates: first evidence and possible mechanisms. Drugs 59: 391-399, 2000

187. Hiraga T, Williams PJ, Mundy GR, Yoneda T: The bisphosphonate ibandronate promotes apoptosis in MDA-MB-231 human breast cancer cells in bone metastases. Cancer Res 61: 4418-4424, 2001

188. Smith PC, Hobish A, Lin D, Culig Z, Keller ET: Interleukin-6 and prostate cancer progression. Cytokine Growth Factor Rev 12: 33-40, 2001

189. Lum L, Wong BR, Josien R, Becherer JD, ErdjumentBromage H, Schlondorff J, Tempst P, Choi Y, Blobel CP: Evidence for a role of a tumor necrosis factor-alpha (TNFalpha)- converting enzyme-like protease in shedding of TRANCE, a TNF family member involved in osteoclastogenesis and dendritic cell survival. J Biol Chem 274: 13613-13618, 1999

190. Lacey DL, Timms E, Tan HL, Kelley MJ, Dunstan CR, Burgess T, Elliott R, Colombero A, Elliott G, Scully S, Hsu H, Sullivan J, Hawkins N, Davy E, Capparelli C, Eli A, Qian YX, Kaufman S, Sarosi I, Shalhoub V, Senaldi G, Guo J, Delaney J, Boyle WJ: Osteoprotegerin ligand is a cytokine that regulates osteoclast differentiation and activation. Cell 93: 165-176, 1998

191. Kong YY, Yoshida H, Sarosi I, Tan HL, Timms E, Capparelli C, Morony S, Oliveira-dos-Santos AJ, Van G, Itie A, Khoo W, Wakeham A, Dunstan CR, Lacey DL, Mak TW, Boyle WJ, Penninger JM: OPGL is a key regulator of osteoclastogenesis, lymphocyte development and lymph-node organogenesis. Nature 397: 315-323, 1999

192. Yasuda H, Shima N, Nakagawa N, Yamaguchi K, Kinosaki M, Mochizuki S, Tomoyasu A, Yano K, Goto M, Murakami A, Tsuda E, Morinaga T, Higashio K, Udagawa N, Takahashi N, Suda T: Osteoclast differentiation factor is a ligand for osteoprotegerin/osteoclastogenesis-inhibitory factor and is identical to TRANCE/RANKL. Proc Natl Acad Sci USA 95: 3597-3602, 1998

193. Fuller K, Wong B, Fox S, Choi Y, Chambers TJ: TRANCE is necessary and sufficient for osteoblast-mediated activation of bone resorption in osteoclasts. J Exp Med 188: 997-1001, 1998 
194. Tsuda E, Goto M, Mochizuki S, Yano K, Kobayashi F, Morinaga T, Higashio K: Isolation of a novel cytokine from human fibroblasts that specifically inhibits osteoclastogenesis. Biochem Biophys Res Commun 234: 137-142, 1997

195. Tan KB, Harrop J, Reddy M, Young P, Terrett J, Emery J, Moore G, Truneh A: Characterization of a novel TNF-like ligand and recently described TNF ligand and TNF receptor superfamily genes and their constitutive and inducible expression in hematopoietic and non-hematopoietic cells. Gene 204: 35-46, 1997

196. Yasuda H, Shima N, Nakagawa N, Mochizuki SI, Yano K, Fujise N, Sato Y, Goto M, Yamaguchi K, Kuriyama M, Kanno T, Murakami A, Tsuda E, Morinaga T, Higashio K: Identity of osteoclastogenesis inhibitory factor (OCIF) and osteoprotegerin (OPG): a mechanism by which OPG/OCIF inhibits osteoclastogenesis in vitro. Endocrinology 139: 1329-1337, 1998

197. Kwon BS, Wang S, Udagawa N, Haridas V, Lee ZH, Kim KK, Oh KO, Greene J, Li Y, Su J, Gentz R, Aggarwal $\mathrm{BB}, \mathrm{Ni}$ J: TR1, a new member of the tumor necrosis factor receptor superfamily, induces fibroblast proliferation and inhibits osteoclastogenesis and bone resorption. FASEB J 12: 845-854, 1998

198. Yun TJ, Chaudhary PM, Shu GL, Frazer JK, Ewings MK, Schwartz SM, Pascual V, Hood LE, Clark EA OPG/FDCR-1, a TNF receptor family member, is expressed in lymphoid cells and is up-regulated by ligating CD40. J Immunol 161: 6113-6121, 1998

199. Hofbauer LC, Dunstan CR, Spelsberg TC, Riggs BL, Khosla S: Osteoprotegerin production by human osteoblast lineage cells is stimulated by vitamin $\mathrm{D}$, bone morphogenetic protein-2, and cytokines. Biochem Biophys Res Commun 250: 776-781, 1998

200. Hofbauer LC, Heufelder AE: Osteoprotegerin and its cognate ligand: a new paradigm of osteoclastogenesis. Eur J Endocrinol 139: 152-154, 1998

201. Vidal NO, Brandstrom H, Jonsson KB, Ohlsson C: Osteoprotegerin mRNA is expressed in primary human osteoblast-like cells: down-regulation by glucocorticoids. J Endocrinol 159: 191-195, 1998

202. Kartsogiannis V, Zhou H, Horwood NJ, Thomas RJ, Hards DK, Quinn JM, Niforas P, Ng KW, Martin TJ, Gillespie MT: Localization of RANKL (receptor activator of NF kappa B ligand) mRNA and protein in skeletal and extraskeletal tissues. Bone 25: 525-534, 1999

203. Nagai M, Sato N: Reciprocal gene expression of osteoclastogenesis inhibitory factor and osteoclast differentiation factor regulates osteoclast formation. Biochem Biophys Res Commun 257: 719-723, 1999

204. Thomas GP, Baker SU, Eisman JA, Gardiner EM: Changing RANKL/OPG mRNA expression in differentiating murine primary osteoblasts. J Endocrinol 170: 451-460, 2001

205. Hofbauer LC, Heufelder AE, Erben RG: Osteoprotegerin, RANK, and RANK ligand: the good, the bad, and the ugly in rheumatoid arthritis. J Rheumatol 28: 685-687, 2001

206. Fazzalari NL, Kuliwaba JS, Atkins GJ, Forwood MR, Findlay DM: The ratio of messenger RNA levels of receptor activator of nuclear factor kappaB ligand to osteoprotegerin correlates with bone remodeling indices in normal human cancellous bone but not in osteoarthritis. J Bone Miner Res 16: 1015-1027, 2001

207. Yoneda T, Sasaki A, Mundy GR: Osteolytic bone metastasis in breast cancer. Breast Cancer Res Treat 32: 73-84, 1994

208. Akatsu T, Ono K, Katayama Y, Tamura T, Nishikawa M, Kugai N, Yamamoto M, Nagata N: The mouse mammary tumor cell line, MMT060562, produces prostaglandin E2 and leukemia inhibitory factor and supports osteoclast formation in vitro via a stromal cell-dependent pathway. $\mathrm{J}$ Bone Miner Res 13: 400-408, 1998

209. Mundy GR: Pathophysiology of cancer-associated hypercalcemia. Semin Oncol 17: 10-15, 1990

210. Roodman GD: Mechanisms of bone lesions in multiple myeloma and lymphoma. Cancer 80: 1557-1563, 1997

211. Thomas T, Lafage-Proust MH: Contribution of genetically modified mouse models to the elucidation of bone physiology. Rev Rhum Engl Ed 66: 728-735, 1999

212. Atkins GJ, Bouralexis S, Haynes DR, Graves SE, Geary SM, Evdokiou A, Zannettino AC, Hay S, Findlay DM: Osteoprotegerin inhibits osteoclast formation and bone resorbing activity in giant cell tumors of bone. Bone 28: 370-377, 2001

213. Han JH, Choi SJ, Kurihara N, Koide M, Oba Y, Roodman GD: Macrophage inflammatory protein-1alpha is an osteoclastogenic factor in myeloma that is independent of receptor activator of nuclear factor kappaB ligand. Blood 97: 3349-3353, 2001

214. Guise TA, Yin JJ, Taylor SD, Kumagai Y, Dallas M, Boyce BF, Yoneda T, Mundy GR: Evidence for a causal role of parathyroid hormone-related protein in the pathogenesis of human breast cancer-mediated osteolysis. J Clin Invest 98: 1544-1549, 1996

215. Sasaki A, Boyce BF, Story B, Wright KR, Chapman M, Boyce R, Mundy GR, Yoneda T: Bisphosphonate risedronate reduces metastatic human breast cancer burden in bone in nude mice. Cancer Res 55: 3551-3557, 1995

216. Michigami T, Ihara-Watanabe M, Yamazaki M, Ozono K: Receptor activator of nuclear factor kappaB ligand (RANKL) is a key molecule of osteoclast formation for bone metastasis in a newly developed model of human neuroblastoma. Cancer Res 61: 1637-1644, 2001

217. Oyajobi BO, Anderson DM, Traianedes K, Williams PJ, Yoneda T, Mundy GR: Therapeutic efficacy of a soluble receptor activator of nuclear factor kappaB-IgG $\mathrm{Fc}$ fusion protein in suppressing bone resorption and hypercalcemia in a model of humoral hypercalcemia of malignancy. Cancer Res 61: 2572-2578, 2001

218. John A, Tuszynski G: The role of matrix metalloproteinases in tumor angiogenesis and tumor metastasis. Pathol Oncol Res 7: 14-23, 2001

219. Boag AH, Young ID: Immunohistochemical analysis of type IV collagenase expression in prostatic hyperplasia and adenocarcinoma. Mod Pathol 6: 65-68, 1993

220. Bodey B, Bodey B, Jr., Siegel SE, Kaiser HE: Immunocytochemical detection of matrix metalloproteinase expression in prostate cancer. In vivo 15: 65-70, 2001 
221. Festuccia C, Bologna M, Vicentini C, Tacconelli A, Miano R, Violini S, Mackay AR: Increased matrix metalloproteinase-9 secretion in short-term tissue cultures of prostatic tumor cells. Int J Cancer 69: 386-393, 1996

222. Hamdy FC, Fadlon EJ, Cottam D, Lawry J, Thurrell W, Silcocks PB, Anderson JB, Williams JL, Rees RC: Matrix metalloproteinase 9 expression in primary human prostatic adenocarcinoma and benign prostatic hyperplasia. $\mathrm{Br} \mathrm{J}$ Cancer 69: 177-182, 1994

223. Hashimoto K, Kihira Y, Matuo Y, Usui T: Expression of matrix metalloproteinase-7 and tissue inhibitor of metalloproteinase-1 in human prostate. J Urol 160: 1872-1876, 1998

224. Montironi R, Fabris G, Lucarini G, Biagini G: Location of 72-kd metalloproteinase (type IV collagenase) in untreated prostatic adenocarcinoma. Pathol Res Pract 191: 1140-1146, 1995

225. Montironi R, Lucarini G, Castaldini C, Galluzzi CM, Biagini G, Fabris G: Immunohistochemical evaluation of type IV collagenase (72-kd metalloproteinase) in prostatic intraepithelial neoplasia. Anticancer Res 16: 2057-2062, 1996

226. Pajouh MS, Nagle RB, Breathnach R, Finch JS, Brawer MK, Bowden GT: Expression of metalloproteinase genes in human prostate cancer. J Cancer Res Clin Oncol 117: 144-150, 1991

227. Duivenvoorden WC, Hirte HW, Singh G: Use of tetracycline as an inhibitor of matrix metalloproteinase activity secreted by human bone-metastasizing cancer cells Invasion Metastasis 17: 312-322, 1997

228. Sanchez-Sweatman OH, Orr FW, Singh G: Human metastatic prostate PC3 cell lines degrade bone using matrix metalloproteinases. Invasion Metastasis 18: 297-305, 1998

229. Lee J, Weber M, Mejia S, Bone E, Watson P, Orr W: A matrix metalloproteinase inhibitor, batimastat, retards the development of osteolytic bone metastases by MDA-MB-231 human breast cancer cells in Balb C nu/nu mice. Eur J Cancer 37: 106-113, 2001

230. Nemeth JA, Yousif R, Herzog M, Che M, Upadhyay J, Shekarriz B, Bhagat S, Mullins C, Fridman R, Cher ML: Matrix metalloproteinases activity, bone matrix turnover and tumor cell proliferation in prostate cancer bone metastasis. J Natl Cancer Inst 94: 17-25, 2002

231. Pirtskhalaishvili G, Nelson JB: Endothelium - derived factors as paracrine mediators of prostate cancer progression. Prostate 44: 77-87, 2000

232. Perkel VS, Mohan S, Baylink DJ, Linkhart TA: An inhibitory insulin-like growth factor binding protein (In-IGFBP) from human prostatic cell conditioned medium reveals $\mathrm{N}$-terminal sequence identity with bone derived In-IGFBP. J Clin Endocrinol Metab 71: 533-535, 1990

233. Taguchi Y, Yamamoto M, Yamate T, Lin SC, Mocharla H, DeTogni P, Nakayama N, Boyce BF, Abe E, Manolagas SC: Interleukin-6-type cytokines stimulate mesenchymal progenitor differentiation toward the osteoblastic lineage. Proc Assoc Am Physicians 110: 559574, 1998

234. Le Brun G, Aubin P, Soliman H, Ropiquet F, Villette JM, Berthon P, Creminon C, Cussenot O, Fiet J: Upregulation of endothelin 1 and its precursor by IL-1beta, TNF-alpha, and TGF-beta in the PC3 human prostate cancer cell line. Cytokine 11: 157-162, 1999

235. Goltzman D, Karaplis AC, Kremer R, Rabbani SA: Molecular basis of the spectrum of skeletal complications of neoplasia. Cancer 88: 2903-2908, 2000

Address for offprints: Evan T. Keller, Room 5304 CCGCB, 1500 East Medical Center Drive, Ann Arbor, MI 48109-0940 USA; e-mail: etkeller@umich.edu 